\title{
'A GREATER DANGER THAN A DIVISION OF THE GERMAN ARMY': BIBLE STUDENTS AND OPPOSITON TO WAR IN WORLD WAR I AMERICA
}

\author{
Zoe Knox ${ }^{1}$
}

In June 1918, a small but high-profile Christian community based in Brooklyn, New York City was all but destroyed when seven of its leaders, including the president, were convicted under the United States Espionage Act and sentenced to twenty years in prison. They called themselves Bible Students but were popularly known as Russellites; in 1931 the community was renamed Jehovah's Witnesses. The men were found to be subversives - in the opinion of the Court, their 'religious propaganda' was 'a greater danger than a division of the German Army' ${ }^{2}$ - who must be prevented from disseminating their anti-war message and obstructing America's prosecution of the war. The trial and conviction demonstrate the action taken by the US government to silence those opposed to its April 1917 entry into World War I, particularly communities invoking the Bible to condemn militarism and conflict. It also reveals the challenges posed by a religious group that objected to war on grounds very different from those of the historic peace churches, with which government authorities were more familiar and for whom they usually had some sympathy. The Bible Students' premillennial apocalypticism distinguished them from the Church of the Brethren, Religious Society of Friends (Quakers), and Mennonites, as it did most other Christian pacifists. The Bible Students were regarded as pessimistic, if not destructive. Moreover, they were not pacifists. Like Witnesses today, they believed righteous wars were possible but only those directed by Jehovah God and not those waged by earthly governments. These unusual views were widely propagated through Bible Student literature, which the Court ruled was a potent weapon against the American war effort.

By the time the war broke out in August 1914, the Bible Students had been around for forty years. The community emerged in the 1870 s when small, loose-knit groups (called 'ecclesias') met to study scripture guided by tracts written by Charles Taze ('Pastor') Russell, a businessman from Allegheny City, Pennsylvania (later merged into Pittsburgh.). Russell believed that Christian churches had distorted a number of fundamental teachings of Jesus Christ and the apostles, and he made it his mission to seek the truth in the Bible and spread it to all, chiefly through the printed page. Zion's Watch Tower and Herald of Christ's Presence, the forerunner of today's Watchtower magazine, first appeared in $1879 .{ }^{3}$ The ecclesias eventually became collectively known as Bible Students. The beliefs of the Bible Student differed from the standard Christian canon in elemental 
ways, and included the rejection of the Trinity, denial of the existence of hell, and belief in Christ's invisible, rather than physical, return to the Earth. ${ }^{4}$ Although now largely forgotten, Russell was a household name in turn-of-the-century America. His departure from the mainstream churches earned him both a loyal following and many opponents in his lifetime. After Russell's death in October 1916, the New York Times noted that his 'Sunday sermons' had appeared in over 2,000 newspapers, more than 700,000 copies of books in his Studies in the Scriptures series had been published every year since 1886, and he had been involved in two high-profile legal disputes. ${ }^{5}$

This article seeks to write the Bible Students into the history of opposition to war not in spite of but because of their unusual position on Christianity and armed conflict. Russell's teachings regarding the appropriate response of Christians to military service will be considered. Russell's attitude to combatant service was first articulated in 1896 (when conscription was an abstraction) but continued to evolve until his death. It was profoundly shaped by the early stages of World War I. Joseph Franklin ('Judge') Rutherford, who succeeded Russell as president, also provided contemporary commentary on the conflict. His position was outlined in the twelve-page pamphlet Militarism: How will it be Forever Destroyed?, published in late 1915. ${ }^{6}$ The Witnesses' current position on war derives from Russell and Rutherford, although the Watch Tower organization, the corporate body of the Witnesses, attributes its teaching on the issue solely to biblical imperative.

The Bible Students' opposition to war is not a story of anti-war activism on the periphery of the American religious landscape. The International Bible Students Association (IBSA) made national headlines when the entire leadership was tried under the Espionage Act of 1917. The USA's entry into the war in April of that year was accompanied by measures to eliminate domestic resistance to America's war effort, and the Act was the chief instrument to achieve this. The introduction of conscription through the Selective Service Act, passed in May 1917, further ensured the Bible Students were on a collision course with the federal government. While exemptions were guaranteed for members of "any well recognized religious sect or organization," the Bible Students were not in that category. ${ }^{7}$ Unlike most Christian communities, which quickly rallied around the government whatever their pre-war position had been, the Bible Students upheld their staunch opposition, aggressively promoting their belief that war was a result of devilish design and a product of the bloodlust of governments and clergy. US entry into the war also marked the start of a hypernationalistic discourse that was accompanied by a search for the enemy within. The catalyst for the 1918 trial was the book The Finished Mystery, published by IBSA in July 1917. Its condemnation of patriotism, the war in Europe, and earthly governments led to the trial. This and other printed 
material produced by the Bible Students led to the ruling that IBSA leaders had violated the Espionage Act on four counts. Finally, the article will examine the influence of the conviction on the Watch Tower organization, which now counts more than 8 million active members in 240 lands. $^{8}$ The 1918 trial profoundly shaped the organization worldwide but is virtually unknown.

The year 1914 was of utmost significance in Russell's chronology of the end-times. He had long taught that it would mark the return of rule by Christ. For Russell, World War I affirmed Christ's invisible return; on the morning of 2 October 1914, he announced to workers at the IBSA's Brooklyn headquarters: "The Gentile Times have ended: their kings have had their day," a reference to Luke 21:24. ${ }^{9}$ In February 1918, Rutherford reiterated that 1914 was a watershed year, writing: "The physical facts, the fulfilled prophecy and prophecy further in course of fulfillment, prove overwhelmingly and beyond a shadow of a doubt that the Lord is present, that the world has ended, that the kingdom of heaven is at hand!"10 The Bible Students were not the only ones for whom World War I was a sign of the end but, uniquely, the Watch Tower organization maintains that 1914 marked a discontinuity in human history and the beginning of a violent age, as Russell had prophesized. ${ }^{11}$ It teaches that Jesus began ruling the Kingdom of God in 1914 and cast Satan out from the heavenly sanctuary. ${ }^{12}$ The Kingdom will soon replace worldly governments and carry out Jehovah's will upon the earth. Witnesses regard this as imminent and teach that humanity is living in its 'last days' (2 Timothy 3:1-5; Matthew 24:3-14), hence the urgency of spreading their message of salvation.

\section{A Doubly Hidden History}

Exploration of military and political topics dominates historical analyses of the United States and World War I. Opposition to war remains a minor (albeit expanding) theme, pointing to a greater appetite, scholastically speaking, for war than peace. Studies of conscientious objection focus on the struggle of the historic peace churches to respond to rising militarism before America's entry in to the war and the introduction of conscription that followed it. The Bible Students have been relegated to the margins of the social and religious history of World War I; they have been almost entirely absent from studies of opposition to war, in the United States as in other combatant countries. ${ }^{13}$ There have been various explanations for this oversight, one of the least persuasive offered by a leading historian of the war who wrote that Bible Students "have been too ill-educated and socially marginal to have left records of their collective experience...", contrasting them with Quakers. ${ }^{14}$ As Gary Perkins, an amateur historian and Jehovah's Witness, has noted there is plenty of information to be found in the pages of The Watch Tower and Herald of Christ's Presence of which the Oxford 
don seemed unaware. ${ }^{15}$ Perkins argued that research into British Bible Students and World War I was stymied by the fact that they 'deliberately kept a low profile' after the war, since they did not want to be regarded as opponents of government. ${ }^{16}$ This observation does not hold for the United States, where the 'Russellites' were far better known. And yet, Russell's sole biographer elides his position on war in just a few scattered sentences. ${ }^{17}$ The only published study of Bible Students in World War I America, an essay by a pioneering historian of the community (and ex-Witness) M. James Penton, focuses primarily on disputing the Watch Tower organization's long-standing claim that the government's case against IBSA leaders was the result of a campaign instigated by Catholic and Protestant clergy. ${ }^{18}$ As such, Penton is less concerned with the trial itself than he is with establishing that the organization's narrative is erroneous. ${ }^{19}$

The dearth of historical scholarship on this controversial community is not limited to wartime; Jehovah's Witnesses have been largely absent from religious history with the exception of a few notable contexts, chief among them Supreme Court cases in the United States in the middle decades of the twentieth century and their persecution in Nazi Germany. ${ }^{20}$ In recent years, historians have shed light on Witness history in other countries, notably the Soviet Union. Their research is only beginning to fill not so much a gap as a yawning chasm in our understanding of this religious group. ${ }^{21}$ The historiographical lacunae vis-à-vis Bible Students and World War I has been compounded by the broader challenges of researching the community. ${ }^{22}$ In brief, the Watch Tower organization does not make its archives or libraries accessible to outsiders. The organization does not encourage Witnesses to investigate or critique any aspect of its own history. There is, therefore, only a small amount of material on Witness history, most of it comprising official accounts which are sanitized and self-referential. Critiques by ex-members are very often biased and bitter. They offer limited insights into the early history of the organization.

There are ample resources to examine the IBSA's opposition to war, the trial and conviction of its leadership, and the implications of the judgment for the Watch Tower organization. This article draws on work by Russell, the founder-leader, who penned numerous essays on war and military service, and Rutherford, who likewise was a prodigious writer. The book at the center of the trial, The Finished Mystery, sold in large numbers (according to the Society, the $850,000^{\text {th }}$ copy had been printed within six months of the book's release). ${ }^{23}$ The proceedings of the trial against the eight men, which lasted fourteen days, along with the evidence submitted to court was reproduced in two volumes prepared by a dissenting group which continues to regard Russell as a fountainhead (unlike today's organization). ${ }^{24}$ The compilation, which runs to 1,493 pages, makes clear the government's 
concerns about the Bible Students' anti-war discourse. It also reveals in more depth the leadership's deliberations when The Finished Mystery was under preparation. One of those convicted, namely A. H. Macmillan, a long-time associate of Russell's, published a first-hand account of the period. ${ }^{25}$ The Watch Tower organization regards the persecution of Bible Students (and later Jehovah's Witnesses) as evidence of its righteousness and highlights these experiences in its literature. This article draws on these accounts, while remaining cognizant of their intended audience. Finally, the case generated significant interest at the time, and reports in American newspapers on the trial have also been consulted.

\section{Charles Russell and the War in Europe}

Like most Christian thinkers, Russell turned to Romans 13 for an understanding of the Christian's relationship to governmental authority. Russell understood that the 'superior authorities' referred to by Paul the Apostle in Romans 13:1-2 meant civil government. Paul instructs: "Let every soul be subject unto the higher powers. For there is no power but of God: the powers that be are ordained of God. Whosoever therefore resisteth the power, resisteth the ordinance of God."' Russell concluded from this passage that Christians ought to respect civil authorities and regard their actions as part of Jehovah's plan. In The Divine Plan of the Ages, the first volume in the Studies in the Scriptures series, published in 1886, Russell wrote: "Evil as these Gentile governments have been, they were permitted or "ordained of God" for a wise purpose (Romans 13:1)." ${ }^{26}$ He wrote that Christians should be good citizens, paying taxes and respecting state laws unless these conflicted with God's laws (a position the organization continues to this day, emphasizing that Witnesses should be upstanding citizens). ${ }^{27} \mathrm{He}$ advised Bible Students to avoid involvement in political affairs whenever possible but to ultimately obey superior authorities, even when they had to compromise their beliefs. By the time of his death he had abandoned this position.

Many of the articles and editorials in Zion's Watch Tower and Herald of Christ's Presence were published without attribution, although we can be certain that Russell, as president of the organization and editor of the publication, either penned or approved all of them. In an 1896 article reflecting on war, Zion's Watch Tower addressed the issue of military service. It stated: "Filled with the spirit of the Captain of our salvation, we cannot be otherwise than opposed to the destruction of human lives, our desire on the contrary being to save them." ${ }^{28}$ Russell believed the Bible instructed Christians not to kill. Even at this early stage, he was aware that this position would likely be regarded as unpatriotic, a concern which proved prescient. ${ }^{29}$ However - and here the organization's view of the degree of authority vested in earthly government is made clear - the article continued 
that if called up for military service, Bible Students should fulfill this requirement: "If compelled by the government to enter the army, we should "go" (Matthew 5:41), but probably could get into the hospital service." ${ }^{30}$ This position was far from an endorsement of war, but neither was it advocating resistance to war.

The following decade, Russell wrote about the obligations of a Christian in the modern world in The New Creation (1904), volume 6 of Studies in the Scriptures. If called up for military duty, Christians should accept that this must be the Lord's will and obey government authorities. ${ }^{31}$ They were advised to request duties in the medical corps where "our services could be used with the full consent of our consciences." ${ }^{32}$ The most startling guidance given to readers of The New Creation was that although they might fulfill military service "...even if compelled to serve in the ranks and to fire our guns we need not feel compelled to shoot a fellow-creature."'. ${ }^{33}$ In other words, the Bible Students should aim to miss their target (which would likely have placed their lives at risk). Russell wrote approvingly of the exemptions some governments had granted "some who, like ourselves, believe war to be unrighteous," citing the "very gracious provision of this kind" made for Quakers. ${ }^{34}$ The historic Quaker peace testimony was well known to authorities, which could therefore anticipate their opposition to bearing arms and make provisions for them. Russell's views were more recent, not widely known, and perhaps confusing to authorities because he advised compliance with government regulations on military service and only stopped short of spilling blood. Moreover, his guidance in The New Creation was general and largely divorced from concrete conditions of conflict.

Russell's guidance led many Bible Students to fulfill military service when conscripted. In September 1915, an article in The Watch Tower stated that Bible Students serving in the army were in touch with the headquarters, noting: "Bible students from the different armies from time to time give us word of their welfare and of their endeavor to hold up the Light and to show forth the Lord's praises, even under such terrible conditions." ${ }^{35}$ Letters published in the magazine show that regular readers, in some cases likely but not certain Bible Students, were serving in European armies in various capacities. ${ }^{36}$ It is not difficult to comprehend the challenges that Russell's advice caused for Bible Students called up to serve. Joseph Rutherford wrote that in retaliation for their request for exemption from combat duty, Bible Students in the German army were instead placed on the front lines. They would not shoot and so were killed themselves (they 'were amongst the first to fall', according to Rutherford). ${ }^{37}$ In its official history, published in 1993, the Watch Tower organization reports that Bible Students serving on the front in World War I fired their weapons into the air or 
tried to knock weapons from their opponents' hands instead of shooting in order to comply with the Bible's command not to kill. ${ }^{38}$

Although the war in Europe resulted in a shift in the IBSA's position, this did not take immediate effect. Despite the mounting death toll, it advised Bible Students not to oppose governments, on the issue of war or any other, but instead to remain "in subjection to the superior authorities." This was most clearly articulated in an editorial in The Watch Tower in July 1915. It noted that the organization had received inquiries about how Bible Students ought to respond to the war in Europe, perhaps enlisting in the hospital corps in order to forestall being conscripted. It reminded readers that it was not the role of the Christian to challenge government authority but instead God should decide on such matters: "To be "subject to the powers that be", implies not merely a willingness to serve under compulsion, but implies also that we will not oppose earthly governments in any public manner." It was a caution not to oppose government in the mistaken belief this might change the course of events. The editorial continued: 'The public reproof and overthrow will come from the Lord' ${ }^{39}$ This Bible-based reflection on service was followed by a table of Red Cross Society figures listing the number of killed, seriously wounded, slightly wounded, and prisoners up to that point. ${ }^{40}$

Perkins argues that as the war progressed, it became necessary for the IBSA to clarify its advice, since the guidance published in 1904 and July 1915 was becoming 'impractical' ${ }^{41}$ Increasingly, Bible Students wrote to Russell to seek counsel. Perhaps as a result of these inquiries, an article in The Watch Tower on 1 September 1915 marked a definitive shift in the approach to war. It is clear from the opening sentence that the progression of war had caused a reappraisal ('As the war progresses, a bitter, partisan spirit spreads'). The article revisited the advice given in The New Creation and in the July edition of The Watch Tower and found it a position of compromise. It acknowledged that although inquirers were given '... our best thoughts previously, but [we] now fear that we were too conservative' ${ }^{42}$ A harder line was taken, for example the article explained that to don the military uniform, a necessity when joining the army, would be to recognize and, crucially, accept the duties of a soldier, which contravened Biblical injunction. The new position cannot be interpreted as a defiant, however. It conceded that Bible Students facing financial hardship might be forced to work in munitions factories in order to provide for their families. Although this was not ideal, and those workers should seek to move to other occupations when possible, it was accepted that this might be necessary for some. ${ }^{43}$ 
The article criticized Christian clergy for seizing on support for the war as an opportunity to curry favor with their governments: "Professed ministers of Christ of various denominations seem to be vying with each other in leaving the Great Captain of our Salvation and His standard of peace and love in order to associate themselves more and more with militarism." ${ }^{44}$ To this end, it claimed that they distorted Biblical verse to give apparent support for the war and even participated in recruitment drives. It asked: "Such ministers may gain favor and influence with their earthly king and his ministers and representatives in the government, but how will they stand with the other King, whose Empire is to be inaugurated with the great Battle of Armageddon, to which this present war is leading?"45

There is a clear sense that the IBSA's partially compliant position on military service has been overturned and that Bible Student opposition to serving in any capacity might have some impact. This was acknowledged when considering whether to object to service once in the army, when "a protest made to an officer would be insignificant - the public in general would not know of it." 46 The recognition that the Bible Students' approach might be exposed to the public was new. It was even suggested that their resistance might have far reaching consequences, which countered the July advice to present themselves for service if conscripted. The article stated: "We cannot tell how great the influence would be for peace, for righteousness, for God, if a few hundred of the Lord's faithful were to follow the course of Shadrach, Meshach and Abednego, and refuse to bow down to the god of war."'. ${ }^{47}$ This is as close to a call for action as Russell ever got. Earlier, the suggestion had been that this would have no influence on government actions, or the outcome of war, because such decisions came from God.

The article also considered the possibility Bible Students might be shot for their refusal to don the uniform and serve when conscripted. It stated that if representation was made properly, then they should be exonerated (like the Quakers) but if not: "...would it be any worse to be shot because of loyalty to the Prince of Peace and refusal to disobey His order than to be shot while under the banner of these earthly kings and apparently giving them support and, in appearance at least, compromising the teachings of our Heavenly King?" It was hardly necessary to clarify: "Of the two deaths we would prefer the former-- prefer to die because of faithfulness to our Heavenly King. Certainly the one dying for his loyalty to the principles of the Lord's teachings would accomplish far more by his death than would the one dying in the trenches." 48 Thus, from a compromise position that regarded serving in the army in non-combatant roles as perfectly acceptable, and even a combat role if instructed, albeit without killing, the IBSA position became one of opposition to war. 
At this stage, the organization's leadership gave Bible Students the latitude to determine their own response upon receiving a draft notice. It would therefore be incorrect to consider the organization's stance as uniformly pacifist, given that Bible Students could determine for themselves the right response to military service. One historian of conscientious objection in Britain was therefore incorrect when he wrote that there was no option for Bible Students but to reject service if conscripted. ${ }^{49}$ Russell did not issue instructions on the right approach to war but instead encouraged Bible Students to follow their own conscience. IBSA literature was explicit about this: in September 1915, even after the position had hardened, The Watch Tower stated: "We are not urging this course. We are merely suggesting it. The responsibility fully belongs with each individual." ${ }^{50}$ Ultimately, it was made clear that authority over the issue of military service lay with Bible Students themselves, and not with the organization.

Russell came under suspicion from governments, as evident from the Canadian authorities forcibly returning him to the United States in July 1916 when he attempted to attend a Bible Student convention in Winnipeg. ${ }^{51} \mathrm{He}$ died later that year, in October 1916, before America's entry into the conflict the following April. Rutherford adopted a position of unequivocal hostility toward secular governments and a position on war that was to have a profound influence on Bible Students (and later Witnesses) worldwide.

\section{Rutherford on Militarism}

Little is known of Rutherford's life prior to his involvement with the Bible Students. He studied law and shorthand before becoming a court reporter in Boonville, Missouri where in 1891 a brief profile in The National Stenographer noted his expertise in a particular form of shorthand. ${ }^{52}$ According to an article in Time magazine in 1930, in the 1890s Rutherford campaigned for the threetime Democratic presidential nominee William Jennings Bryan. ${ }^{53}$ The details of Rutherford's role in Bryan's 1896 campaign and of his nascent political career are obscure, but he evidently retained a loyalty and respect for him well after he left party-political affairs behind, as evident from the reference to Bryan in Militarism: How will it be Forever Destroyed? Although Rutherford's detractors have alleged that the moniker 'Judge' is undeserved and misleading, he briefly served as a judge in his home state of Missouri. ${ }^{54}$

Rutherford became interested in Russell's teachings after buying books in the Studies in the Scriptures (then called Millennial Dawn) series from two Bible Students travelling door-to-door 
selling literature. In a short letter published in Zion's Watch Tower in 1894, Rutherford admitted purchasing the books largely to help the women selling them but, once he eventually read the books, he and his wife were so moved by Russell's message that they bought additional copies to distribute and took out an annual subscription to Zion's Watch Tower. ${ }^{55}$ Although Rutherford was not baptised until 1906, he very quickly rose to a position of prominence within the organisation, becoming its legal counsel in 1907. By the time Militarism appeared in 1915, he had become one of seven directors of the organisation. He enjoyed a high profile in other ways, too. Earlier in 1915, Rutherford engaged in a series of highly publicized debates with a Baptist pastor in the Trinity Auditorium in Downtown Los Angeles and published a 64-page booklet that defended Russell's character against criticism. ${ }^{56}$

Rutherford was visiting Hamburg, Germany in August 1914. In Militarism, he wrote vividly of the panic and despair he witnessed when news of the war spread: 'I saw fathers, sons and brothers being hurriedly taken from their homes and rushed to the front. I saw mothers, wives and children, sad of countenance and with tear-stained faces hurrying through the streets to wave goodbye to their loved ones as they rushed to the battlefield to die' ${ }^{57}$ Rutherford spoke with soldiers and citizens who did not want war and concluded that the conflict was against the will of ordinary people, of every nation. They were the pawns of political machinations rather than supporters of the ostensible causes behind the conflict. He observed that men were under heavy pressure to enlist. Raising a theme that would later be controversial in The Finished Mystery, Rutherford wrote that most disturbing was seeing 'preachers' encouraging men to enlist. ${ }^{58}$

Although he used socialist language to condemn militarism, the substance of Rutherford's attack on government policy was theological. He identified 'selfishness' as the root cause of militarism and war. Cain's murder of Abel was 'the beginnings of Militarism and the first effects of war' ${ }^{59} \mathrm{He}$ explained the link between selfishness and war as a product of the corruption of Christian principles: 'Christ declared that all of his followers are brethren. Brethren are admonished to love one another. Had "Christendom" been the true representatives and followers of Christ, brotherhood would have prevailed. But instead all these nations, while claiming to be Christian have cultivated the spirit of selfishness' ${ }^{60}$ Instead of encouraging 'strife and blood letting', he advised clergy to 'humbly take up the banner of the cross and bear its message of peace'. ${ }^{61}$ Later, the cross was denounced as a pagan holdover and expunged from the Bible Students' theological vocabulary, but here it was presented as a symbol of Christian love. 
Rutherford wrote that the Bible foretold that every nation would be drawn into the war. Although some - and the sole example provided is Bryan - were doing their utmost to prevent preparedness for war and forestall the USA's entry into the conflict, these efforts were well intended but ultimately futile, since '... there is no earthly power that can now prevent the United States being involved in the great and final conflict' ${ }^{62}$ In case there was any room for misinterpretation, Rutherford reiterated: "The doom of Babylon is sealed. The United States composes part of Babylon.". 63

Rutherford closed Militarism by reminding readers that the Bible foretold the precise year in which the war would start: $1914 .{ }^{64}$ He thus supported Russell's calculations of the beginning of the end-times. The answer to the question of the pamphlet's sub-title was thus revealed: the end of militarism would not be secured by any nation achieving victory in war but instead by the wholesale destruction of the existing order and the creation of the kingdom of heaven on earth. ${ }^{65}$ With this, 'selfishness will be supplanted by love' - and thus the amassing of the weapons of war would end. ${ }^{66}$ The end to war would be secured by heavenly government, not by anti-war agitation or social unrest. This marked Rutherford apart from religious pacifists of the day, most of who were seeking to nurture war resistance within faith communities.

\section{Publication of The Finished Mystery}

The Finished Mystery was the seventh and final volume in the series Millennial Dawn, renamed Studies in the Scriptures in 1904 to emphasize the role of the books as aids to Bible study. The first six were written by Russell and laid out his theology, which in some ways was entirely unique and in others similar to the broad Adventist tradition. The seven volumes addressed different topics, ranging from Genesis to the chronology of the end-times. It is important to note that they were published not only for Bible Students but were intended to reach a wide audience. The wide distribution of The Finished Mystery elevated the Bible Student's position on military service to an issue of national concern.

The Finished Mystery was published on 17 July 1917 as Russell's posthumous work ${ }^{67}$ Its authorship was immediately contested. The preface, written by Rutherford, explained that although God had revealed to Russell the truths therein, on his deathbed he outlined his plans and specified that another should write them up. ${ }^{68}$ Clayton Woodworth and George Fisher, close associates of Russell, were entrusted with the task. Curiously, the preface notes that although the men resided in the same city (Scranton, Pennsylvania) they did not confer on the contents of the book, instead 
working independently on different parts based on their study of Russell's work and of Revelation, Ezekiel, and the Song of Solomon. ${ }^{69}$ The harmonization of the different parts of the book, and the book as a whole with Russell's other work, was, according to the preface, 'evidence of the Lord's direction' of the writing project. ${ }^{70}$ It was edited by Rutherford. The extent to which Woodworth and Fisher drew on Russell's work is not known. In both style and content The Finished Mystery is very different from that of the previous six volumes in the series, as Religious Studies scholar George D. Chryssides has observed. ${ }^{71}$

The controversy over authorship seemed largely confined to the Brooklyn headquarters. Rank-and-file Bible Students distributed The Finished Mystery widely and enthusiastically. By the close of 1917, the 850,000th volume was in print. An article in The Watch Tower claimed that this number of sales in such a short time surpassed the demand for any other book in history apart from the Bible. ${ }^{72}$ The Finished Mystery is almost 600 pages long. Most of it comprises commentary on the books of Revelation, Ezekiel and the Song of Solomon. Only eight pages (247 to 253) were discussed at the trial. This section referred to the war in Europe (when the book went to the printers, the United States had yet to enter the conflict).

The controversial section opened with a paragraph that condemned patriotism in the strongest terms, as a satanic aberration: "The three fundamental truths of history are man's Fall, Redemption and Restoration. Stated in other language these three truths are the mortal nature of man, the Christ of God and His Millennial Kingdom. Standing opposite to these Satan has placed three great untruths, human immortality, the Anti-christ and a certain delusion which is best described by the word Patriotism, but which is in reality murder, the spirit of the very Devil."73 Patriotism was defined as 'a narrow-minded hatred of other peoples'. ${ }^{74}$ It was responsible for 'the human butchery which has turned the earth into a slaughter-house' ${ }^{75}$ The book noted that in the Bible, 'Everywhere and always murder in its every guise is forbidden; and yet, under the guise of Patriotism the civil governments of earth demand of peace-loving men the sacrifice of themselves and their loved ones and the butchery of their fellows, and hail it as a duty demanded by the laws of heaven'. ${ }^{76}$ This was an unequivocal charge of the bloodlust of the governments participating in the war and of the clergy who supported them.

The condemnation of patriotism was followed by a lengthy extract from an essay by the Reverend Charles E. Jefferson, although only a close reading would identify it as such. The extract began with quotation marks but without any acknowledgment of its authorship (this only appeared at 
the close of the extract, two pages later, which was standard format in Watch Tower literature). Although not acknowledged in The Finished Mystery, Jefferson was a Congregationalist pastor at the Brooklyn Tabernacle Church (and thus a near neighbor of the IBSA). Jefferson also had a rich pedigree as a pacifist: he was one of the founders of the New York Peace Society. He noted the clamor for war prior to 1914 and condemned militarism as the "most virulent and devastating disease of humanity now raging on the earth..." ${ }^{77}$ Like a disease, he wrote that militarism is contagious: 'One nation can be infected by another until there is an epidemic around the world' ${ }^{78} \mathrm{He}$ condemned the diversion of resources to the army and navy when there was hunger, poverty and disease in the combatant nations. ${ }^{79}$

Jefferson's piece was followed by another lengthy excerpt, this one taken from an essay by John Haynes Holmes, a prominent Unitarian pastor, pacifist and civil libertarian (and early admirer of Mahatma Gandhi). Again, the author was not named until the close of the quotation. ${ }^{80}$ It opened with a striking and typically provocative statement by Holmes: "War is in open and utter violation of Christianity. If war is right, then Christianity is wrong, false, a lie. If Christianity is right, then war is wrong, false, a lie." ${ }^{81} \mathrm{He}$ argued that the conflict was due to commercial and national interests. Holmes concluded with fiery prose: "There is not a question raised, an issue involved, a cause at stake, which is worth the life of one blue-jacket on the sea or one khaki-coat in the trenches." ${ }^{82}$ By presenting parts of an essay by Holmes, the Bible Students were - unwittingly, perhaps - aligning themselves with a well-known antiwar activist. Holmes' widely read 1916 treatise New Wars for Old was sub-titled Being a Statement of Radical Pacifism in Terms of Force Versus Non-Resistance, With Special Reference to the Facts and Problems of the Great War. Readers knew where Holmes stood. He was merely identified in The Finished Mystery as from the Church of the Messiah on Park Avenue in New York City. ${ }^{83}$

The book then turned to the role of the mainstream Christian churches in garnering support for the war. It included extracts from an article by Russell in The Bible Students Monthly which blamed 'the sects and creeds of Christendom' for turning people away from real Christianity. ${ }^{84}$ It presented short extracts from three articles in various issues of Zion's Watch Tower in 1915 which emphasized the role of the clergy in encouraging men to enlist and fight, accusing them of "acting as recruiting agents. ${ }^{15}$ Another excerpt recounted that a priest in khaki was participating in a recruitment drive: "Asked by a college friend, Did I see you in the ranks?" he answered, 'Yes, I wanted to encourage the boys.' 'And did you think of going to the front, to the trenches? "Not a bit of 
it!'” He was merely acting as a decoy to get others to the front..." 86 Thus, to the charge of war mongering was added hypocrisy.

The Finished Mystery was banned in Canada on 12 February 1918, along with a pamphlet issued by the Watch Tower organization that reproduced parts of it. Penton argued that developments in Canada 'inspired' American authorities to move against the IBSA. ${ }^{87}$ The day after the Canadian ban, the United States government seized copies of the book. Its publication was attributed to German agents. ${ }^{88}$

\section{IBSA Leaders on Trial}

In May 1918, eight IBSA leaders (Rutherford, Fisher and Woodworth among them) were charged under the Espionage Act. Material was seized from the headquarters at 13-17 Hicks Street in Brooklyn, including letters, report books, pamphlets, financial records, books, and files relating to the Italian and German branches. ${ }^{89}$ By this stage, Rutherford was aware of the controversy surrounding The Finished Mystery and had already halted the printing and distribution of the book. He ordered the controversial pages removed and the text replaced with new plates. ${ }^{90}$ This and other concessionary moves mattered little to the authorities, however. ${ }^{91}$ The trial began on 3 June in the District Court for the Eastern District of New York in Brooklyn. The prosecution alleged that the men 'persistently urge insubordination, disloyalty and refusal of duty in the ... military and naval services of the United States of America...' and that their actions amounted to a conspiracy to undermine the country's war effort. ${ }^{92}$ The prosecution gave as evidence articles in Bible Student's Monthly, Watch Tower, Kingdom News and "other pamphlets not named," but focused firmly on The Finished Mystery. ${ }^{93}$

In the trial's opening stages, the prosecution's chief concern was to establish the chronology of the drafting, editing and printing of the book. Whether or not it was written after US entry into the war or after the Espionage Act was passed would apparently indicate how intentionally the IBSA leadership had undermined the American war effort. The Finished Mystery was printed in July, one month after the passage of the Act, which meant that if it was found to have seditious content, it was unlawful. This had particular implications for the interpretation of a passage on page 247 titled: 'Come out of the mouth of the dragon'. The prosecutors argued this was an explicit call for Americans to agitate for the country's withdrawal from the conflict. ${ }^{94}$ 
The extended discussion of chronology allowed considerable detail to emerge about the way literature was written at this very early stage in the organization's post-Russell history. The way the book was written would indicate whether or not its publication was a concerted conspiracy on the part of IBSA leaders or simply an explication of their interpretation of Revelation, Ezekiel and the Song of Solomon, as they claimed. Rutherford testified that Russell had already written parts of the book, namely 'something on Revelations [sic] and something on Ezekiel', but the prosecution was intent on establishing the authorship and approval of passages that they considered encouraged opposition to war. ${ }^{95}$

The transcript reveals a number of facts about the composition of The Finished Mystery. First, although both Fisher and Woodworth lived in Scranton, the two men worked largely in isolation on different parts of the book, not even sharing news of their progress when they did meet. ${ }^{96}$ This meant that, although the volume was co-authored, the men could identify who had written particular passages. Fisher was able to identify Woodworth as the author of the paragraphs on patriotism, for example. ${ }^{97}$ Second, The Finished Mystery was started soon after Russell's death and completed quickly. Fisher and Woodworth first met in late November 1916 to discuss the book, began writing it the following month, and completed their work by February. ${ }^{98}$ The rapid progress was likely hastened by the fact that Woodworth had worked on his portions a decade earlier, drawing on text on Revelation he prepared for the Berian Bible Students' Manual. Presumably this meant he tweaked existing draft material rather than wrote entirely new content. ${ }^{99}$ Thirdly, there was little awareness among the other IBSA leaders about its preparation. Even Alexander Macmillan, a longtime associate of Russell's and key figure in the organization, first learned of the book when shown the manuscript by Rutherford as late as 6 June. ${ }^{100}$ Finally, Rutherford was not heavily involved in determining the content of The Finished Mystery. Fisher testified that Rutherford did not suggest what he ought to write in his commentary on Ezekiel and Woodworth said that he only met with Rutherford twice when he was preparing his sections. ${ }^{101}$ Rutherford's role was revealed to be the final approver of the book rather than anything more involved.

The prosecution was concerned to establish who the key figures were within the IBSA, and repeatedly sought clarification of the men's roles. ${ }^{102}$ This was important to determine who ultimately gave the order for printing The Finished Mystery. Rutherford, as president, was quite obviously at the helm, with Macmillan in charge when he was away. ${ }^{103}$ Interestingly, Rutherford was at pains to state that the key figure in the organization was Charles Russell, since the Bible Students followed 
his teachings. Rutherford was later reluctant to emphasize Russell's importance, or indeed that of any individual, to the organization.

The longevity of the IBSA's anti-war position was an important issue at trial. In an affidavit written in August 1917, and presented to court in June, William Van Amburgh wrote that the Bible Students had long been firmly against war, adhering 'strictly and literally' to the teachings of Jesus and the apostles to be peaceful. ${ }^{104}$ He pointed out that this position was reiterated repeatedly in Bible Student literature, quoting extensively from the article 'Christian Duty and the War' by way of example. ${ }^{105}$ The Bible Students were, according to Van Amburgh, against war in any form and would not take human life under any circumstances. ${ }^{106}$ At trial, it was important for the prosecution to establish the Bible Students' anti-war position because their proselytism could, in this case, be viewed as an attempt to convert people not just to their religious beliefs but also to their opposition to war. ${ }^{107}$ Bizarrely, William F. Hudgings suggested just the opposite to Van Amburgh: he stated that World War I was so central to Russell's prophetic system that to be against the war would mean the Bible Students were against their own beliefs! ${ }^{108}$ Martin testified that he had no objection to politicians deciding to wage war but he did oppose the participation of "those who have made a consecration" since they were not supposed to kill. ${ }^{109}$

Aside from the passage on patriotism, the most controversial part of The Finished Mystery was a section that began: "Out of the mouth of the dragon..." The prosecution alleged that this referred to the United States' role in the war. During the trial, Woodworth clarified that the message applied to all people, rather than those of one particular nation, alive at the time and in the future. ${ }^{110}$ Rutherford contradicted Woodworth by testifying that, on the contrary, it was a reference to the people of Europe, where he had seen first-hand how nations had turned on each other and thought 'it expressed a narrow-minded hatred far from patriotism'. ${ }^{111}$ Rutherford was adamant that the section was not a reference to the United States, thereby refuting that the book incited Americans to anti-war agitation.

The Jefferson excerpt in The Finished Mystery prompted another line of inquiry. As mentioned earlier, it appears without any introductory comment or indication of either its authorship or original context. The extract was taken directly from an earlier reproduction in The Watch Tower. The prosecution revealed that there were inaccuracies in its reproduction and alleged that its origins as a speech delivered at a "peace conference" had been obscured. ${ }^{112}$ The implication was that the Bible Students had sought to hide the fact it was written by Jefferson, a well-known pacifist. 
Indicating his limited involvement with the content of the book, Rutherford admitted that he would not have included the text by Holmes or Jefferson if he had given the matter proper reflection. ${ }^{113}$ Fisher testified that he had not read either of the extracts until after the book was published, pointing to poor coordination of the book's overall form and content. ${ }^{114}$

Throughout the proceedings, the IBSA leaders expressed their surprise not only at the popularity of The Finished Mystery but also at the controversy it generated. ${ }^{115}$ They saw the book as a strictly religious, rather than a political, treatise. Fisher stated: 'I thought of it as a religious book and not a book that was for political effect in any way whatever', a position reiterated by Woodworth. ${ }^{116}$ Both Van Amburgh and Roy Robison claimed that the first point at which they were aware it might be found objectionable was in March 1918, when the book was banned in Canada and Bible Students in Pennsylvania were arrested for its distribution. ${ }^{117}$ Martin testified that The Finished Mystery was not a doctrinal book but instead a prophetic one, with a focus on predicting future events rather than commenting on contemporary ones. ${ }^{118} \mathrm{He}$ thus argued that its content was not a commentary on the wartime context.

Given Russell's shifting position on military service, it is hardly surprising that IBSA headquarters received a large number of inquiries asking how Bible Students should respond when drafted. The prosecution alleged that an anti-war attitude was imparted to inquirers who were not Bible Students and that the organization was therefore spreading the anti-war message beyond its own community and to the broader public. The indictment documents include letters to Jerry de Cecca, the brother of Giovanni de Cecca, one of the IBSA leaders, encouraging Jerry to continue his refusal to join the hospital service, wear a soldier's uniform, and in other ways stand fast against the pressures of the authorities in Camp Devens, Massachusetts where he been called for training. ${ }^{119}$ The advice given by the organization should be seen in the broader context of the confusion and delay over President Woodrow Wilson's provisions for noncombatant service.

The Wilson administration was slow to clarify its position and the interim arrangements were unclear. Robison, who answered written queries when Rutherford was away, wrote to one draftee, W. E. Drain, advising him not to accept military service in any form since Wilson had not clarified what arrangements might be made for him as a religious CO once he had. ${ }^{120}$ Drain could jeopardize his chances of exemption by presenting himself to military authorities. The Bible Students distributed advice under the misapprehension that until Wilson had clarified the terms, which they thought imminent, noncombatant service was voluntary rather than obligatory. ${ }^{121}$ The prosecution 
put to Robison that the real motivation behind the guidance was that he "intended to hinder the enforcement of the Selective Service Act and the building up of our Army." 122 Van Amburgh testified: "They were all conscientious objectors, as far as I knew, who already have [sic] made up their minds before the book was published. If that book was never published and the draft act had come up, the inquiries would be just the same. ${ }^{123}$ The IBSA men showed a wariness of spurious claims to Bible Student affiliation motivated by the belief this would relieve neophytes of the obligation to serve if conscripted. They called these inquiries 'decoy letters' and responded coolly. ${ }^{124}$

The men were convicted on all four counts of violating the Espionage Act. They were found guilty of conspiring to cause insubordination, disloyalty and refusal of duty in the military; conspiring to obstruct recruitment and enlistment into the army; of attempting to cause insubordination by discouraging those already in the military to perform, and to refuse, their duties; and of obstructing recruitment and enlistment to the detriment of the United States' war effort. ${ }^{125}$ In his comments, Judge Howe was clear that the Bible Students posed a grave danger to the country:

In the opinion of the Court, the religious propaganda which these defendants have vigorously advocated and spread throughout the nation as well as among our allies, is a greater danger than a division of the German Army. If they had taken guns and swords and joined the German Army, the harm they could have done would have been insignificant compared with the results of their propaganda. A person preaching religion usually has much influence, and if he is sincere, he is all the more effective. This aggravates rather than mitigates the wrong they have done. Therefore, as the only prudent thing to do with such persons, the Court has concluded that the punishment should be severe. ${ }^{126}$

The punishment was indeed harsh. On 21 June 1918, seven of the men were sentenced to 80 years in prison, twenty years on each of four counts, to run concurrently. This was the maximum sentence permitted under the Act. De Cecca was later sentenced to 10 years; his case had been considered separately and the conclusion reached was that he had not been as central to the production and distribution of The Finished Mystery as his associates. ${ }^{127}$ The men were initially sent to Brooklyn's Raymond Street Jail (described by Macmillan as 'the dirtiest hole I ever got into' ${ }^{\text {'28) }}$ ) then to Long Island City prison and, on 4 July, transferred to a Federal Penitentiary in Atlanta, Georgia.

Following an appeal by the Society, the judgment was reversed. On 25 March 1919, after nine months, the men were released on the grounds that the trial was not impartial. ${ }^{129}$ By this time, the war was over. But the implications of the trial and conviction for the Bible Students had just begun.

\section{Implications of the Case}


The conviction of Rutherford and his associates in 1918 was seen by the Bible Students, as by Witnesses today, as evidence of their righteousness. In recounting the story of the wartime trial, the Watch Tower's official history observed that the very same charge of sedition was made against Jesus Christ and the apostle Paul by the religious establishment in first century Jerusalem. It noted that, as in Jesus' time, the clergy, furious at their 'exposure', were behind the attempts to silence the Christian message, here represented by the campaign to ban The Finished Mystery. ${ }^{130}$ The conviction was welcomed by Rutherford. The New-York Tribune quoted him as saying on his journey from courtroom to jail: "This is the happiest day of my life. To serve earthly punishment for the sake of one's religious belief is one of the greatest privileges a man could have."131

The most significant consequence of the case for the Watch Tower organization was the personal authority that it conferred on Rutherford. He had been elected president in January 1917, six months before The Finished Mystery appeared. His role in facilitating its publication led to his conviction by the court and, conversely, his lionization within the organization. This was furthered by Rutherford's apparent defiance in the face of efforts to marginalize Bible Students. He vowed to continue preaching Russell's message during his confinement. The IBSA men preached to other inmates; eventually Rutherford, Macmillan and De Cecca even ran Sunday school classes for their fellow prisoners. ${ }^{132}$ The refusal not to be cowed marked Rutherford as dedicated to Russell's teachings, and no doubt the lengthy sentence fed into the sense that he was a martyr for the cause. It increased his authority and enabled him to introduce radical changes that define the organization to this day. There were, of course, many religious COs imprisoned for their opposition to the war, but this was not (and is not) acknowledged in the organization's accounts, which 'reflects a parochialism', according to Barbara Grizutti Harrison, a former resident and worker at the headquarters, since these present the experience as evidence of Rutherford's 'special relationship with God' rather than part of a wider story of religious conscientious objection. ${ }^{133}$

Rutherford successfully introduced policies that marked a radical departure from Russell's leadership. For example, Rutherford emphasized the need for Bible Students to engage in public ministry and, to this end, expanded the door knocking campaign which has since become perhaps the best known of the community's practices (in the organization's own words, 'house-to-house ministry' is the 'trademark' of Jehovah's Witnesses ${ }^{134}$ ). Under Rutherford's tenure Watch Tower literature became characterized by its histrionic condemnation of Protestantism and especially Roman Catholicism. Russell's spiritual journey had begun when he questioned the teachings of the Christian churches, but he regarded them as misguided and deluded rather than deceptive. In 
contrast, Rutherford believed that the churches were motivated by political power, in bed with big business, and rotten to the core, seeking to draw people away from Christianity. ${ }^{135}$ The fact Catholic and Protestant clergy had supported the campaign against The Finished Mystery likely fueled this shift. For Rutherford, World War I revealed the intimate connection between the military-industrial complex and the churches. The Watch Tower organization continues to teach that the Christian churches are of Babylon, although in a more measured manner than the screeds of the Rutherford era. ${ }^{136}$ It is unlikely that the Bible Student community would have accepted these two shifts without the personal authority conferred on Rutherford as a result of his imprisonment for espionage. Although a large number of Bible Students left the organization over what they regarded as departures from Russell's teachings, discussed further below, Rutherford's authority was such that his group retained the Watch Tower name, commanded the loyalty of key associates of Russell (such as Macmillan), secured the corporation's assets, and perhaps most importantly, retained control of all of its publications.

A second consequence of the case was that the Bible Students became a coherent, identifiable religious community. Russell did not intend to found a new church, nor did he see himself as having any special spiritual authority or divine gift. But as his profile rose, a distinct identity for his followers gradually began to emerge. This was rapidly consolidated in the Rutherford era, with the publication of The Finished Mystery as the catalyst. The controversy within the organization over authorship led to the emergence of schismatic groups that rejected Rutherford's leadership. In 1918, from the Atlanta penitentiary, Rutherford condemned the schism in the strongest terms, seeing it as evidence of 'creature worship'. ${ }^{137}$ He believed that a cult of personality had developed around Russell. ${ }^{138}$ While in prison, Rutherford was re-elected president, confirming his authority over the organization Russell founded, not the other contenders for the post.

As a result, a large number of Bible Students left the Watch Tower organization. One insider at the world headquarters estimated that three-quarters of those associated with the movement left between 1921 and 1931. ${ }^{139}$ The leadership struggle ultimately served to cleanse the organization of those with a wavering or half-hearted commitment to Rutherford. Jerry Bergman, a former Witness, identified more than 40 different groups that emerged as a result. ${ }^{140}$ Some of them are still in existence but most have long since disappeared. It is only Rutherford's organization that has any significant following. In 1931, Rutherford announced that henceforth, Bible Students would be known as "Jehovah's witnesses," based on Isaiah 43: 10, 12: "Ye are my witnesses, saith the 
Lord." ${ }^{141}$ He taught that they were the exclusive bearers of the Christian message. The new name was the culmination of the process that began with the trial.

Bible Students were first subjected to widespread opprobrium during World War I. Russell had raised the hackles of Protestant and Catholic clergy before the war (to the point where one wellknown Methodist minister in Los Angeles fumigated his pulpit after finding out that "Russellites' had hired the hall and preached from it $^{142}$ ) but their critiques were largely focused on theological points or comprised personal attacks on Russell, and did not take aim at Bible Student practices broadly speaking. This changed with World War I. In July 1918, Shirley Jackson Case, a theologian from the University of Chicago's Divinity School, identified them as an example of the insidious and pervasive threat of premillennialism to the United States in its most testing hour. He argued the belief that the end of the world was imminent and part of a divine plan led to inaction in the face of the German foe. Their preachers were "mission[aries] of pessimism" who encouraged Americans to not only disengage from but to oppose the war effort. Like other premillennial groups, Jackson contended that Bible Students were a valuable aid to the Germans, one step away from the Industrial Workers of the World (an international socialist union), and "a pronounced enemy of democracy and a serious menace to the nation's morale in this hour of its need." ${ }^{143}$ An editorial in the New York Times approved of the conviction of the IBSA men, opining that the right of government "to defend and perpetuate itself" was appropriately held above the right to the free exercise of religion. ${ }^{144}$ The historian Amy Shaw has argued that in Canada, while it was the attacks on Protestantism and especially Catholicism which prompted the government to ban Bible Student literature, they were not popularly regarded as a problem. As the war dragged on, however, the biblical basis of their objection to war led to increased public antagonism towards the community. ${ }^{145}$

By identifying the Bible Students as aiding the German foe, whether intentionally or not, Judge Howe, Shirley Jackson Case and others tarred the community with the same brush as other perceived enemies of the American government. There were attacks on Bible Students across the country as a result. These included the seizure of literature without a warrant, physical assaults, including of women and children, and imprisonment without charge. More than 100 instances of persecution were recorded in the IBSA periodical The Golden Age by September $1920 .{ }^{146}$ Bible Students became widely known for their refusal to support the American war effort. Witnesses faced far more widespread hostility and intense persecution in World War II but there was continuity with the maligned status gained during World War I. ${ }^{147}$ 
Finally, Charles Russell taught that Bible Students should respect the laws of civil authorities except where they contravened the laws of Jehovah. This extended to serving in the army if conscripted (albeit without shooting to kill). This can hardly be considered resistance to war. While he opposed military service after the start of the war, conscientious objection only emerged as a clear doctrine in the 1920s. In particular, two articles written by Rutherford on the 'superior authorities' of Romans 13 provided clarity. Rutherford offered the example of military service to demonstrate the clear limits on a Christian's subjection to secular authorities: 'If commanded by the ruling powers of the nation to go to war and kill, in order to be faithful to the commandment of God he must refuse to go to war'. ${ }^{148}$ As in the Militarism booklet, other Christian churches were fiercely condemned for their support for conflict and especially for their part in recruitment efforts. That the same churches in different countries could support opposite sides of the conflict was given as evidence of the divided nature of these churches.

Rutherford argued that the ultimate outcome of conflict was determined by Jehovah and not by earthly governments. In 1938, with World War II looming, he advised Witnesses not to join the fight against Hitler's forces: "The Totalitarian combine is going to get control of England and America. You cannot prevent it. Do not try. Your safety is on the Lord's side." ${ }^{149}$ The following year, in November, a lengthy article called 'Neutrality' appeared in The Watchtower (and was also produced as a booklet). It specified that Witnesses must be completely neutral when it comes to worldly affairs and that to participate in, or support, military activities would be to violate the doctrine of neutrality. ${ }^{150}$ Under Rutherford's leadership, the Watch Tower organization developed clear positions on both political neutrality and conscientious objection. This set the scene for legal conflict between American Witnesses and the US government after World War II broke out, when conscription was again necessary to raise a sizeable army and hyper-nationalism was the order of the day.

\section{Conclusion}

By World War I, conscientious objection to war had expanded beyond the historic peace churches. This posed a significant challenge to American policy-makers, who no longer satisfied opponents of war by offering concessions to Mennonites, Quakers and other better-known Christian pacifist groups. The historic peace churches were somewhat familiar to the political establishment; they were the more acceptable face of the conscientious objector. ${ }^{151}$ The increasingly diverse group of secular and religious COs demanded a new approach, one slow to gain traction with political and religious authorities. The Bible Students posed one of the greatest challenges. They were viewed as 
profoundly out of step with the prevailing mood after the United States entered the conflict. Most other American Christians quickly threw their support behind the government, some even regarding it as a holy war. ${ }^{152}$ The Bible Students condemned patriotism in the strongest terms and promoted an apocalyptic vision of the end times that countered both the common Christian pacifist narrative of peace and the claims of the wartime state to be fighting the good fight to protect the freedoms of ordinary Americans. Indeed, IBSA discourse was so belligerent towards the government that it seemed to align Russell and his associates with organizations already identified as hostile to America, like the Industrial Workers of the World. Furthermore, the theological grounds for IBSA's position were unpalatable to the political and religious establishments, who sought to cast Bible Student theology on war as a seditious political position. Earthly governments were part of the system of Babylon, the corrupt, fallen world. IBSA literature taught that the bloodlust of government and the complicity of Christian clergy in the conflict provided firm evidence of this. The apocalypticism of the Bible Students made them appear as opponents not only of the conflict but, as Case argued, of the optimism and belief in progress that characterized America in times of both war and peace. The Bible Students enjoyed little sympathy, nor did they seek it.

It is clear from the trial and the broader response to the Bible Students that American authorities regarded the circulation of their literature as a genuine and serious threat to the war effort. ${ }^{153}$ The condemnation of patriotism and criticism of combatant governments, the advice given to young men to refuse to serve, and the reproduction of anti-war essays by high-profile Christian pacifists gave the book an apparent ideological position - one which was aligned them with America's enemies. The fear that Bible Student literature would encourage a groundswell of support for conscientious objectors, or provide an excuse for "shirkers", is evident in the trial documents. As Duane Stoltzfus has shown in his study of Hutterites, the number of religious COs in the United States in World War I was tiny when compared to the size of the army, something which makes the brutal and unforgiving response to his pacifist subjects impossible to understand without grasping the height of wartime hysteria. ${ }^{154}$ Similarly, the crackdown on Bible Student literature reveals the government's misplaced concern that religious COs would hinder the raising of an army.

The outcome of the trial looked as though it would destroy the Bible Student community. Its leaders imprisoned, the Brooklyn headquarters closed, the organization run by an inexperienced executive board, subjected to political censure and public opprobrium, and organizationally divided, the Bible Students seemed so divided and decimated that it was unlikely there might be any recovery. By the organization's own admission, in 1918 'the preaching of the good news' - the very 
raison d'être of the organization 'came to a virtual standstill'. ${ }^{155}$ It looked set to become one of the many groups derived from the broad umbrella of the Adventist movement destined for obscurity in the early twentieth century. On the contrary, the group led by Rutherford gained authority over rankand-file members. The conviction conveyed a personal authority on Rutherford that allowed him to introduce far-reaching changes, which, already by the early 1930s, rendered the organization almost unrecognizable from the one founded by Russell. There is much in the early years of the movement, which was not only no longer standard practice but was inconceivable by the middle of the twentieth century. The Bible Student community grew in notoriety, becoming widely known for its refusal to support the American war effort. Finally, opposition to war became a firm doctrine for the organization, one that brought Witnesses into conflict with governments of all stripes as the twentieth century progressed. Rather than securing the demise of the group, the trial during World War I not only influenced but also defined the modern-day organization.

Although the IBSA leaders were released in 1919, the basic tension between their apocalyptic theology and the demands of wartime government went unresolved, which became evident with the onset of World War II. ${ }^{156}$ Jehovah's Witnesses were subjected to mob violence across America in the early 1940s, a level of persecution described by the American Civil Liberties Union as 'unparalleled in America since the attacks on the Mormons' in the nineteenth century. ${ }^{157}$ It is not only in the US context that Witnesses have come under suspicion. From Malawi and Australia to Singapore and the Soviet Union, Witnesses have been cast as potential enemies of the state. ${ }^{158}$ They persist in viewing the Bible (specifically their translation of the Bible, the New World Translation) as the ultimate source of authority and not civil authorities.

Writing the community into the narrative of pacifism and peace history is challenging, for two reasons. First, they are not against war in all scenarios and therefore are not pacifists. Wars fought by Jehovah are tolerated. Second, Witnesses expect violence, chaos and disorder, regarding it as evidence that humanity is living in 'the last days'. It heralds the onset of a battle, after which only those who accept the truth - as understood by the Watch Tower organization - will be saved. This war, waged by God, is central to their theology. This has obscured the importance of IBSA among the variety of religiously inspired opponents of World War I and how one small but high profile community challenged the American government on grounds at once familiar (anti-militarism, Christian pacifism) and unfamiliar (apocalyptic). 
For scholars of Witness history, a burgeoning sub-field of religious history, the 1918 trial should be central to an understanding of the history of the organization. The trial materials reveal a great deal about the way The Finished Mystery was written and produced and more broadly about the inner workings of IBSA in its formative years. The voices of ordinary Bible Student COs who suffered as a consequence of their conviction also need to be uncovered. It is essential to 'unmute' the voices of the Bible Students despite, or perhaps because of, their unorthodox position in the history of anti-war agitation. ${ }^{159}$ Their experiences in World War I America shed light on wartime fears, at both elite and popular levels, the history of religious conscientious objection, of which they are an important if irregular component, and the early history of one of the most controversial religious groups to emerge from the spiritual ferment of nineteenth century America.

\footnotetext{
${ }^{1}$ I am grateful to George D. Chryssides and Andrew Johnstone for feedback on an earlier draft of this article. I have also benefited from questions and comments from audiences at the following conferences: 'Faith and the First World War' at the University of Glasgow, 2016; 'Remembering Muted Voices' at The National WWI Museum and Memorial in Kansas City, Missouri, 2017; and 'Religious Freedom' at the University of Eastern Finland in Joensuu, 2018.

2 'Opinion of the Court, 21 June 1918', The Case of the International Bible Students Association: Volume II (Clayton, CA: Witnesses, Inc., 1918), 1164. Hereafter the title will be rendered The Case of the IBSA: Vol. II.

${ }^{3}$ Formally known as The Watchtower Announcing Jehovah's Kingdom, this is the most widely distributed periodical in the world today. It has had a number of different titles since 1879, all slight variations on the original. Most references here are to The Watch Tower and Herald of Christ's Presence, its title from 1909 to 1931.

${ }^{4}$ For an overview of the Watch Tower organization's beliefs and practices, see G. D. Chryssides, Jehovah's Witnesses: Continuity and Change (Farnham: Ashgate, 2016).

5 'Pastor Russell Dies in Texas Train', New York Times, 1 November 1916: 11.

${ }^{6}$ J. F. Rutherford, Militarism: How will it be Forever Destroyed?' (Norristown, PA: Associated Bible Students [no date]). The booklet must have been written in late 1915 because the opening passages indicate that World War I had been underway for just over a year.

${ }^{7}$ Selective Service Act of 1917, Pub.L 65-12.

${ }^{8}$ Watch Tower Bible and Tract Society of Pennsylvania, 2017 Yearbook of Jehovah's Witnesses (Watchtower Bible and Tract Society of New York, Inc.: Wallkill, NY, 2016), 177. The word 'lands' is used instead of countries because, to take one example, the figures for Puerto Rico are given separately from those for the United States.

${ }^{9}$ A.H. Macmillan, Faith on the March (Englewood Cliffs, New Jersey: Prentice-Hall, Inc., 1957), 46-47.

${ }^{10} \mathrm{~J}$. F. Rutherford, The Harp of God: Proof Conclusive that Millions Now Living Will Never Die; a Text-book for Bible Study Specially Adapted for Use of Beginners; with Numerous Questions and Scripture Citations (London: International Bible Students Association, 1924), 250.

${ }^{11}$ The sense that the war marked the apogee of something was common to those who foresaw the imminent end of the current order. For example, in June 1918, Joseph Hofer, a Hutterite from South Dakota imprisoned for his refusal to fulfill military service, wrote a letter to his wife from his confinement in Camp Lewis in Washington. He wrote that God '...has promised that he will be with us until the end of the world, which is not very far off. Christ said there will be wars and rumors of wars. And this is now fulfilled'. Hofer died in Fort Leavenworth, Kansas. Duane C. S. Stoltzfus, Pacifists in Chains: The Persecution of Hutterites during the Great War (Washington, D.C.: John Hopkins University Press, 2013), 31 .

12 "The Four Horsemen: Who are They?', The Watchtower (Public Edition) no. 3 (2017): 5.

${ }^{13}$ Typical is one classic study that called them a 'minor religious group' (albeit one with 'many zealous and devoted followers') and dedicated just three paragraphs to 'Russellites'. H. C. Peterson \& Gilbert C. Fite, Opponents of War, 1917-1918 (Madison: The University of Wisconsin Press, 1957), 119-120. More recent studies of the American churches and the war refer to Bible Students only in a cursory way, if at all, sometimes erroneously referring to them as 'Jehovah's Witnesses', a name first used over a decade after the war ended. Richard M. Gamble, 'Between God and Caesar: World
} 
War I and America's Religious Communities' in Stephen J. Stein (ed.), The Cambridge History of Religions in America (Cambridge: Cambridge University Press, 2000), 644.

${ }^{14}$ Martin Ceadel, 'The Opposition to War' in Peter Liddle, John Bourne \& Ian Whitehead (eds), The Great World War 1914-45: Volume 2: The Peoples' Experience (London: Harper Collins Publishers, 2001), 435. There is no evidence to support Ceadel's suggestion that Bible Students were mostly uneducated and/or impoverished. On the contrary, the emphasis on literature points to high levels of literacy and sufficient money to purchase it.

${ }^{15}$ Gary Perkins, Bible Student Conscientious Objectors in World War One - Britain (Poland: Hupomone Press, 2016), 166.

${ }^{16}$ Perkins, Bible Student Conscientious Objectors, 166. Perkins offers two other explanations for the historiographical lacunae on British Bible Students that are less compelling. He suggests that the change of name to Jehovah's Witnesses in 1931 may have confused scholars to the extent that they did not research them and more simply that studying Bible Students "isn't trendy enough for some" (166).

${ }^{17}$ Zydek also appears to conflate conscientious objection with the popular view (before 1916) that the USA should keep out of the war. Fredrick Zydek, Charles Taze Russell: His Life and Times. The Man, the Millennium and the Message (Connecticut: Winthrop Press, 2010), 373; 378; 394.

18 This allegation is also made in the seminal study Ray H. Abrams, Preachers Present Arms: A Study of the War-time Attitudes and Activities of the Churches and the Clergy in the United States, 1914-1918 (Philadelphia: Round Table Press, 1933), 182-185.

${ }^{19}$ M. James Penton, 'The Bible Students / Jehovah's Witnesses in the United States during the First World War' in Gordon L. Heath (ed.), American Churches and the First World War (Eugene, Oregon: Pickwick, 2016), 149-166. He concludes that it was 'police, the secret service and the military' which prompted US officials to take the IBSA leaders to court (163).

${ }^{20}$ On the United States, see S. Barringer Gordon, The Spirit of the Law: Religious Voices and the Constitution in Modern America (Cambridge, Mass \& London: The Belnap Press of Harvard University Press, 2010), 15-55; J. Jacobs Henderson, Defending the Good News: The Jehovah's Witnesses' Plan to Expand the First Amendment (Spokane, WA: Marquette Books, 2010); S. F. Peters, Judging Jehovah's Witnesses: Religious Persecution and the Dawn of the Rights Revolution (Lawrence, Kansas: University Press of Kansas, 2000). On Germany, see D. Garbe, Between Resistance and Martyrdom: Jehovah's Witnesses in the Third Reich (Madison (WI): University of Wisconsin Press, 2008) and M. J. Penton, Jehovah's Witnesses and the Third Reich: Sectarian Politics under Persecution (Toronto, Buffalo, London: University of Toronto Press, 2004).

${ }^{21}$ E. B. Baran, Dissent on the Margins: How Soviet Jehovah's Witnesses Defied Communism and Lived to Preach About It (Oxford, New York: Oxford University Press, 2014); Z. Knox, 'Preaching the Kingdom Message: The Jehovah's Witnesses and Soviet Secularization' in C. Wanner (ed.), State Secularism and Lived Religion in Soviet Russia and Ukraine (Oxford \& New York: Oxford University Press, 2012), 244-271. Other national contexts are explored in: G. Besier \& K. Stokłosa (eds), Jehovah's Witnesses in Europe: Past and Present Volume 1/2 and Volume 2/2 (Cambridge Scholars Publishing: Newcastle, 2016); Zoe Knox, Jehovah's Witnesses and the Secular World: From the 1870s to the Present (London: Palgrave Macmillan, 2018); and The Jehovah's Witnesses in Scholarly Perspective: What is New in the Scientific Study of the Movement?, Acta Comparanda: Subsidia III (Antwerp: Faculty for Comparative Study of Religion and Humanism, 2016).

22 Zoe Knox, 'Writing Witness History: The Historiography of the Jehovah's Witnesses and the Watch Tower Bible and Tract Society of Pennsylvania', Journal of Religious History 35, no. 2, (2011), 157-180 and Zoe Knox, 'The History of Jehovah's Witnesses: An Appraisal of Recent Scholarship', Journal of Religious History 41, no. 2 (June 2017), 251-260. ${ }^{23}$ Watch Tower Bible and Tract Society of Pennsylvania, Jehovah's Witnesses: Proclaimers of God's Kingdom (New York: Watchtower Bible and Tract Society of New York, Inc., 1993), 69.

${ }^{24}$ The Case of the International Bible Students Association: Volume I (hereafter The Case of the IBSA: Vol. I) and The Case of the IBSA: Vol. II (Clayton, CA: Witnesses, Inc., 1918).

${ }^{25}$ Macmillan, Faith on the March.

${ }^{26}$ C. T. Russell, The Divine Plan of the Ages: As Shown in the Great Pyramid (London: International Bible Students Association, 1886 [1915]), 318. The edition consulted specifies a publication date of 1886, but this cannot be correct given the reference to IBSA in London, which was established later. A special edition volume was reprinted in 1915, so the book referenced here must have been published in 1915.

27 “"Maintain Your Conduct Fine Among the Nations", The Watchtower, 1 November 2002: 9-14.

28 'Views from the Tower', Zion's Watch Tower and Herald of Christ's Presence, 1 January 1896: 3.

29 'Views from the Tower': 3. Steveson argued that Bible Student leaders had explored the implications of their position on secular authority well before conflict over war and were aware that this would cause tension with the state. Linda Lou Steveson, 'The Bible Students and World War I: Conflict between an Indigenous American Apocalyptic Movement and Governmental Authorities', Unpublished MA Thesis, University of Montana, 1973, 2.

${ }^{30}$ Italics in the original. 'Views from the Tower', Zion's Watch Tower, 1 January 1896: 3. The verse cited by Russell reads, '...if someone under authority impresses you into service for a mile, go with him two miles'. 
31 '...if required, we would be obliged to obey the powers that be, and should consider that the Lord's providence had permitted the conscription and that he was able to overrule it to the good of ourselves and others'. C. T. Russell, The New Creation (Brooklyn, NYC: Watch Tower Bible and Tract Society, 1904), 594-595.

${ }^{32}$ Russell, The New Creation, 595.

${ }^{33}$ Russell, The New Creation, 595.

${ }^{34}$ Russell, The New Creation, 594.

35 'Elijah's Work Before Ascension', The Watch Tower and Herald of Christ's Presence, 1 September 1915: 266.

Hereafter referred to simply as The Watch Tower.

36 'Interesting Letters', The Watch Tower, 15 June 1916: 191.

${ }^{37}$ Joseph Franklin Rutherford, Millions Now Living Will Never Die (Brooklyn, New York: International Bible Students Association, 1920), 83.

${ }^{38}$ Watch Tower Bible and Tract Society of Pennsylvania, Jehovah's Witnesses: Proclaimers, 191.

39 'View from the Watch Tower', The Watch Tower, 1 July 1915: 196.

40 'Killed, Wounded and Prisoners', The Watch Tower, 1 July 1915: 197.

${ }^{41}$ Perkins, Bible Student Conscientious Objectors, 17.

42 'Christian Duty and the War', The Watch Tower, 1 September 1915: 261.

43 'Christian Duty and the War': 260.

44 'Christian Duty and the War': 259.

45 'Christian Duty and the War': 260.

46 'Christian Duty and the War': 260.

47 'Christian Duty and the War': 260.

48 'Christian Duty and the War': 260.

${ }^{49}$ He wrote: '...the element of individual choice was practically eliminated'. John Rae, Conscience and Politics: The British Government and the Conscientious Objector to Military Service, 1916-1919 (London: Oxford University Press, 1970), 74.

50 'Christian Duty and the War': 261.

${ }^{51}$ M. James Penton, Jehovah's Witnesses in Canada: Champions of Freedom of Speech and Worship (Toronto: Macmillan of Canada, 1976), 44.

52 The article observed that Rutherford 'is gradually, but surely, marching toward the top of his profession'. The issue reproduced a page of Rutherford's notes and included the transcript. 'Transcript of Shorthand Plates', The National Stenographer 2, no. 8 (August 1891), 272; 275. I am grateful to contributors to the JW Scholars listserv for bringing this fleeting mention in an obscure periodical to my attention.

${ }^{53}$ Macmillan gives Bryan's anti-war activities as an example of opposition to war, suggesting that the leadership of the organization followed his career. Macmillan, Faith on the March, 84-85. Rutherford's work on Bryan's campaign has been cited by several historians, but no source has been given. See M. James Penton, Apocalypse Delayed: The Story of Jehovah's Witnesses, Third ed. (Toronto: University of Toronto Press, 2015), 416,n.3; Barbara Grizzuti Harrison, Visions of Glory: A History and a Memory of Jehovah's Witnesses (London: Robert Hale, 1980), 112.

${ }^{54}$ For an example of this charge, see Edward Curran, Judge 'For Four Days' Rutherford (Brooklyn: International Catholic Truth Society, 1940). On his work as judge, see 'Joseph F. Rutherford', The Case of the IBSA: Vol. II, 964-965.

55 'Out of Darkness into His Marvelous Light', Zion's Watch Tower, 15 April 1894: 127. For more on Rutherford's 'conversion', see Knox, Jehovah's Witnesses and the Secular World, 36.

${ }^{56}$ G. D. Chryssides, Jehovah's Witnesses: Continuity and Change (Farnham: Ashgate, 2016), 75; J. F. Rutherford, A

Great Battle in the Ecclesiastical Heavens ([no publisher]: New York City, 1915).

${ }^{57}$ Rutherford, Militarism, 2.

${ }^{58}$ Rutherford, Militarism, 3.

${ }^{59}$ Rutherford, Militarism, 4.

${ }^{60}$ Rutherford, Militarism, 7.

${ }^{61}$ Rutherford, Militarism, 11-12.

${ }^{62}$ Rutherford, Militarism, 8.

${ }^{63}$ Rutherford, Militarism, 8.

${ }^{64}$ Rutherford, Militarism, 9.

${ }^{65}$ Rutherford, Militarism, 9-10.

${ }^{66}$ Rutherford, Militarism, 10.

${ }^{67}$ The Preface stated: 'This book may properly be said to be a posthumous publication of Pastor Russell'. Watch Tower Bible \& Tract Society, 'Preface' in Charles T. Russell, The Finished Mystery (Brooklyn, London, Melbourne, Barmen, Elberfeld, Orebro, Christiania: International Bible Student Association, 1917), 5.

68 'In his last moments he said, "Some one else can write the Seventh Volume"'. Watch Tower Bible \& Tract Society, 'Preface' in Russell, The Finished Mystery, 5. Fisher identified Rutherford as the author of the preface. 'George H. Fisher', The Case of the IBSA: Vol. I, 555.

${ }^{69}$ Watch Tower Bible \& Tract Society, 'Preface' in Russell, The Finished Mystery, 6. 
${ }^{70}$ Watch Tower Bible \& Tract Society, 'Preface' in Russell, The Finished Mystery, 6.

${ }^{71}$ George D. Chryssides, 'Finishing the Mystery: The Watch Tower and "the 1917 schism"' in James R Lewis \& Sarah

M. Lewis (eds), Sacred Schisms: How Religions Divide (Cambridge: Cambridge University Press, 2009), 117.

${ }^{72}$ Watch Tower Bible and Tract Society of Pennsylvania, Jehovah's Witnesses: Proclaimers, 69.

${ }^{73}$ Russell, The Finished Mystery, 247.

${ }^{74}$ Russell, The Finished Mystery, 247.

${ }^{75}$ Russell, The Finished Mystery, 247.

${ }^{76}$ Russell, The Finished Mystery, 247.

${ }^{77}$ Russell, The Finished Mystery, 248.

${ }^{78}$ Russell, The Finished Mystery, 249.

${ }^{79}$ Charles E. Jefferson cited in Russell, The Finished Mystery, 248-249.

${ }^{80}$ Russell, The Finished Mystery, 251.

${ }^{81}$ John Haynes Holmes cited in Russell, The Finished Mystery, 250.

${ }^{82}$ Holmes cited in Russell, The Finished Mystery, 251.

${ }^{83}$ Later renamed the Community Church of New York in 1919, after it broke with the American Unitarian Association over the position on World War I. John Haynes Holmes, I Speak for Myself: The Autobiography of John Haynes Holmes (New York: Harper \& Brothers, 1959), 83-84.

${ }^{84}$ Russell, The Finished Mystery, 252. First person used in extract, i.e. 'I'.

${ }^{85}$ Russell, The Finished Mystery, 252.

${ }^{86}$ Russell, The Finished Mystery, 253.

${ }^{87}$ Penton, Apocalypse Delayed, 203.

${ }^{88}$ Philip Jenkins, '"Spy Mad"? Investigating Subversion in Pennsylvania, 1917-1918', Pennsylvania History: A Journal of Mid-Atlantic Studies 63, no. 2 (Spring 1996), 211. Canadian Bible Students were also perceived to be German agents. Amy J. Shaw, Crisis of Conscience: Conscientious Objection in Canada during the First World War (Vancouver, Toronto: UBC Press, 2009), 76; 137.

89 'Petition of Defendant Rutherford', The Case of the IBSA: Vol. I, 100-101.

90 'Joseph F. Rutherford, 17 June 1918', The Case of the IBSA: Vol. II, 965-966.

${ }^{91}$ For example, also in May Rutherford advised readers of Zion's Watch Tower that buying Liberty Bonds was acceptable. Penton, 'The Bible Students / Jehovah's Witnesses in the United States during the First World War', 158. At some point that summer, he visited six Bible Students COs in a camp who refused to take up alternative civilian service and convinced them to accept it. The account of the visit was provided by another prisoner who surmised that this was because Rutherford was facing charges and was under pressure to show that he was not fomenting opposition to war. Timothy M. La Goy, 'Soldiers of Conscience: Conscription and Conscientious Objection in the United States and Britain During World War I', Unpublished PhD Thesis, University at Albany, State University of New York, 2010, 122.

92 'Indictment', The Case of the IBSA: Vol. I, 14.

93 'Indictment', The Case of the IBSA: Vol. I, 12.

94 'George H. Fisher', The Case of the IBSA: Vol. I, 485

95 'Joseph F. Rutherford', The Case of the IBSA: Vol. II, 969-970.

96 'George H. Fisher', The Case of the IBSA: Vol. I, 519.

${ }^{97}$ The Bible Students legal representative therefore argued that Fisher had not written any of the sections of the book the prosecution alleged was subversive. 'Motions', The Case of the IBSA: Vol. I, 434. Interestingly, Fisher admitted that he did not necessarily agree with what was written about patriotism. 'George H. Fisher', The Case of the IBSA: Vol. I, 552. 98 'Roy C. MacHenry', The Case of the IBSA: Vol. I, 217; 'George H. Fisher', The Case of the IBSA: Vol. I, 488.

99 'Clayton J. Woodworth', The Case of the IBSA: Vol. I, 574.

100 'Alexander H. McMillan', The Case of the IBSA: Vol. II, 843. (One of the many spelling errors in the trial material is Macmillan's surname). Similarly, Martin claimed to be entirely unaware even of the book's existence until 11 July 1917, less than a week before it was released.; 'Robert J. Martin', The Case of the IBSA: Vol. II, 889.

101 'Clayton J. Woodworth', The Case of the IBSA: Vol. I, 593; 'George H. Fisher', The Case of the IBSA: Vol. I, 492493.

${ }^{102}$ See, for example, 'William F. Hudgings', The Case of the IBSA: Vol. I, 294.

103 'Mabel Campbell', The Case of the IBSA: Vol. I, 266.

${ }^{104}$ In an affidavit, William E. Van Amburgh wrote: ' $\ldots$ that the creed or principles of said religious organization existing and in force on and prior to the $18^{\text {th }}$ day of May, 1917, forbids its members to participate in war in any form, and are against war in any form; that it and members of said organization adhere strictly and literally to the teachings of Jesus and the Apostles as set forth in the Bible, to wit: "'Thou shalt not kill". "All they that take with the sword shall perish with the sword." "No murderer hath eternal life abiding in him." "Follow peace with all men, and holiness, without which no man shall see the Lord." "The Son of Man came not to destroy men's lives, but to save them". "Ye are called to be footstep followers of Jesus". "As we have opportunity let us do good to all men".' W. E. Van Amburgh, 'Affadavit, 7 August 1917', The Case of the IBSA: Vol. I, 41-42. 
${ }^{105}$ W. E. Van Amburgh, 'Affadavit, 7 August 1917', The Case of the IBSA: Vol. I, 42; 'Christian Duty and the War': 260.

${ }^{106}$ W. E. Van Amburgh, 'Affadavit, 7 August 1917', The Case of the IBSA: Vol. I, 43.

${ }^{107}$ See the line of questioning here: 'Robert J. Martin', The Case of the IBSA: Vol. II, 912.

108 'William F. Hudgings', The Case of the IBSA: Vol. I, 313.

109 'Robert J. Martin', The Case of the IBSA: Vol. II, 900.

110 'Clayton J. Woodworth', The Case of the IBSA: Vol. I, 589.

111 'Joseph F. Rutherford', The Case of the IBSA: Vol. II, 1023.

112 'Clayton J. Woodworth', The Case of the IBSA: Vol. I, 612-613.

113 'Joseph F. Rutherford', The Case of the IBSA: Vol. II, 1052.

114 'George H. Fisher' The Case of the IBSA: Vol. I, 569.

115 'William E. Van Amburgh', The Case of the IBSA: Vol. I, 684; 694.

116 'George H. Fisher', The Case of the IBSA: Vol. I, 571; 'William E. Van Amburgh', The Case of the IBSA: Vol. I, 663.

117 'William E. Van Amburgh', The Case of the IBSA: Vol. I, 664; 'Fred H. Robison', The Case of the IBSA: Vol. II, 756.

118 'Robert J. Martin', The Case of the IBSA: Vol. II, 943.

${ }^{119}$ See several letters included in the indictment materials: The Case of the IBSA: Vol. I, 47-58.

120 'Fred H. Robison', The Case of the IBSA: Vol. II, 775.

${ }^{121}$ This is evident from Robison's testimony and from the content of letters dispensed to inquiries. See 'Fred H.

Robison', The Case of the IBSA: Vol. II, 816; 'Letter from Rutherford to E. Lott, 14 February 1918', The Case of the IBSA: Vol. II, 1239 .

122 'Fred H. Robison', The Case of the IBSA: Vol. II, 832.

123 'William E. Van Amburgh', The Case of the IBSA: Vol. I, 695.

124 'Fred H. Robison', The Case of the IBSA: Vol. II, 803-804; 'Joseph F. Rutherford', The Case of the IBSA: Vol. II, 986.

For a sample response, see 'Defendants' Exhibit P2', The Case of the IBSA: Vol. II, 1321-1322.

125 'Charge', The Case of the IBSA: Vol. II, 1124-1125.

126 'Opinion of the Court, 21 June 1918', The Case of the IBSA: Vol. II, 1164.

127 'Opinion of the Court, 10 July 1918' The Case of the IBSA: Vol. II, 1169.

${ }^{128}$ Macmillan, Faith on the March, 100.

${ }^{129}$ Macmillan, Faith on the March, 108.

${ }^{130}$ Watch Tower Bible and Tract Society of Pennsylvania, Jehovah's Witnesses: Proclaimers, 647. For a refutation of this argument, see Penton, 'The Bible Students / Jehovah's Witnesses in the United States during the First World War'.

${ }^{131}$ The Tribune article appeared in the 22 June 1918 issue. It is cited in Watch Tower Bible and Tract Society of

Pennsylvania, 1975 Yearbook of Jehovah's Witnesses (Brooklyn, NY: Watch Tower Bible and Tract Society, 1976), 108.

${ }_{132}$ Macmillan, Faith on the March, 104.

${ }^{133}$ Harrison, Visions of Glory, 113.

134 'The House-to-House Ministry-Why Important Now?', The Watchtower, 15 August 2008, 3.

${ }^{135}$ See, for example, Joseph Rutherford, Religion: Origin, Influence upon Men and Nations, and the Result (Brooklyn:

Watchtower Bible and Tract Society, 1940) and J. F. Rutherford, Enemies (New York: WTBTS, 1937), 198.

136 'They Tried to Keep God's Word From the Masses', Awake!, December 2011, 8.

${ }_{137}^{137}$ Macmillan, Faith on the March, 106.

${ }^{138}$ For an example of how he sought to stamp this out in Germany, see 'Germany: Part 1', 1974 Yearbook of Jehovah's Witnesses (Brooklyn, NY: Watch Tower Bible and Tract Society, 1973), 97-98.

${ }^{139}$ W. J. Schnell, Thirty Years a Watchtower Slave: The Confessions of a Converted Jehovah's Witnesses Abridged Edition (Grand Rapids, MI: Baker Books, 1971), 42. Harrison likened this period in the organisation's history to 'civil war'. Harrison, Visions of Glory, 11.

140 J. Bergman, Jehovah's Witnesses and Kindred Groups: A Historical Compendium and Bibliography (New York: Garland Pub., 1984).

${ }^{141}$ The new name was also announced in the Watch Tower Bible and Tract Society, 1932 Year Book (London: Watch Tower Bible and Tract Society, 1931), 18; 23.

142 'Flogging given Pastor Russell', Los Angeles Times, 8 February 1915: 1; 8.

${ }^{143}$ Shirley Jackson Case, 'The Premillennial Menace', The Biblical World 52, no. 1 (July 1918), 16-23.

144 'Topics Of The Times', New York Times, 22 June 1918: 8

${ }^{145}$ Shaw, Crisis of Conscience, 73.

${ }^{146}$ See the accounts in '"Distress of Nations": Cause, Warning, Remedy', The Golden Age 1, no. 27 (29 September 1920): 705-725.

${ }^{147}$ Peters, Judging Jehovah's Witnesses; American Civil Liberties Union, The Persecution of Jehovah's Witnesses: The Record of Violence Against a Religious Organization Unparalleled in America since the Attacks on the Mormons (New York City: American Civil Liberties Union, 1941).

${ }^{148}$ J. Rutherford, 'The Higher Powers: Part 2', The Watchtower and Herald of Christ's Presence, 15 June 1929, 183.

149 J. F. Rutherford, Face the Facts (New York: Watch Tower Bible and Tract Society, 1938), 27. 
${ }^{150}$ Watch Tower Bible and Tract Society, Neutrality (Brooklyn Watch Tower Bible and Tract Society, 1939).

${ }^{151}$ Compare the way Quakers and Mennonites are described throughout with the portrayal of the 'Russellites' in Walter Guest Kellogg, The Conscientious Objector (New York \& London: Garland Publishing, 1972). Kellogg was charged with interviewing COs to determine their sincerity.

${ }^{152}$ Gordon L. Heath, 'American Churches and the First World War: An Introduction' in Gordon L. Heath (ed.), American Churches and the First World War (Eugene, Oregon: Pickwick, 2016), 5; Philip Jenkins, The Great and Holy War: How World War I Became a Religious Crusade (New York: HarperOne, 2014).

${ }^{153}$ Also observed at the state level in Jenkins, "Spy Mad"?', 211.

${ }^{154}$ Stoltzfus, Pacifists in Chains, 206-207.

155 Watch Tower Bible and Tract Society of Pennsylvania, Jehovah's Witnesses: Proclaimers, 211.

156 This point is made in Steveson, 'The Bible Students and World War I', 77.

${ }^{157}$ American Civil Liberties Union, The Persecution of Jehovah's Witnesses.

${ }^{158}$ A range of global contexts is explored in Knox, Jehovah's Witnesses and the Secular World.

${ }^{159}$ This may seem ironic given the Supreme Court trial that resulted from their use of amplified sound cars less than two decades later. I. Weiner, Religion Out Loud: Religious Sound, Public Space, and American Pluralism (New York \& London: New York University Press, 2013), 98-135. 